\title{
Geotechnical site investigation and evaluation of 20 March 2019 Mw 5.5 Acıpayam (Denizli) earthquake
}

\section{Mart 2019 Mw 5.5 Acıpayam (Denizli) depreminin jeoteknik saha incelemesi ve değerlendirmesi}

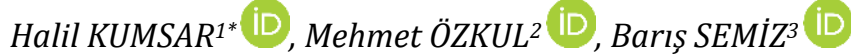 \\ 1,2,3Department of Geological Engineering, Engineering Faculty, Pamukkale University, Denizli, Turkey. \\ hkumsar@pau.edu.tr, mozkul@pau.edu.tr, bsemiz@pau.edu.tr
}

\section{Abstract}

An earthquake with a magnitude of (Mw) 5.5 occurred in Yeniköy village of Acipayam district (Denizli) on 20 Mart 2019 caused heavy damages on masonary structures in Acıpayam basin. Groundwater level from ground surface in the basin varies between $1 \mathrm{~m}$ and $11 \mathrm{~m}$, and soil structure of the basin is made up of silty, gravely and sandy clay. Soil liquefaction was not observed in the basin after the earthquake. The main reasons of the heavy damage on the structures are mainly, high value of soil amplification, use of clayey adobe bricks and hollow bricks for building masonary houses, unpermitted construction of roof floors by using hollow bricks.

Keywords: Acıpayam (Denizli), Earthquake, Geology, Geotechnic.
Öz

20 Mart 2019 tarihinde merkez üssü Denizli ili Acıpayam ilçesinin Yeniköy Mahallesi sinırları içerisinde $5.5(\mathrm{Mw})$ büyüklügünde meydana gelen deprem sonucunda, Acıpayam ovası içindeki yerleșim yerlerinde yığma yapılarda ağır hasarlar meydana gelmiștir. Ova içinde yeraltısuyu derinliği zemin yüzeyinden 1 m-4.5 m arasında değişmektedir ve zemin yapısı genellikle siltli çakıllı ve kumlu kil biriminden olușmaktadır. 5.5 büyüklüğündeki deprem sonrası ova içerisinde zemin sıvılaşması gözlenmemiştir. Yapılardaki ağır hasarların ana nedeni, zemin büyütmesinin yüksek olduğu yerleșim yerlerinde kerpiç, biriket ve delikli tuğla ile yapılmıs yığma yapıların olması ve betonarme yapılarda da mühendislik hizmeti almamış ve dayanımsız yığma çatı katlarının inșa edilmesinden kaynaklanmıștır.

Anahtar kelimeler: Acıpayam (Denizli), Deprem, Jeoloji, Jeoteknik.

\section{Introduction}

An earthquake occurred with a magnitude of $\left(\mathrm{M}_{\mathrm{w}}\right) 5.5$ [1], 5.7 [2] in Yeniköy Village of Acıpayam district in Denizli city in SW Turkey at 09:34 with the local time on 20 March 2019. The hypocenter depth of the earthquake was given as $10.76 \mathrm{~km}$ by [1] and $10.76 \mathrm{~km}$ by [2]. The earthquake caused many adobe and masonry houses to collapse in many villages in the Acıpayam basin (Figure1).

The largest acceleration according to the preliminary assessment results by [1] was measured at 361.24 gal in N-S component, 184.4 gal in E-W component, 30.95 gal in U-D component of AFAD 2017 coded accelerometer station, $7 \mathrm{~km}$ far from the epicenter of the earthquake. The epicenter of the 1936 earthquake with a magnitude of 5.3 [2] was approximately $3 \mathrm{~km}$ far from the 20 March 2019 earthquake.

Fault plane solution of the earthquake given by [3] depicts that NW-SE trending a normal fault caused the earthquake (Figure 2). The earthquake was triggered by the activity of NWSE trending normal fault intersecting Acıpayam fault of the Fethiye-Burdur Fault Zone in the southeast of the basin [4].

The Burdur-Fethiye Fault Zone is one of the important neotectonic and seismic zones of Turkey. There are different studies on paleo-seismology of this neotectonic zone [5]-[12]. Active fault zones in Burdur-Fethiye neotectonic zone (Figure 2) were classified as NE-SW trending, NW-SE trending and N-S trending fault zones 12]. Especially NE-SW trending faults, bounding Burdur Lake from north and south, have left strike slip character.

These faults cut through the Quaternary alluvium sediments in many locations resulting step like morphology with steep slopes. The NW-SE trending faults mostly have normal fault character and they resulted in forming different segments by displacing N-S trending fault zones 12]

Geotechnical investigations [26]-[30] carried out in Acıpayam basin depicted that soft sediments having low SPT values are deposited in the inner part of the basin. In addition to that, groundwater depth from ground surface in the same area varies from $1 \mathrm{~m}$ to $5 \mathrm{~m}$.

In this paper, geotechnical site investigation and evaluation of 20 March $2019 \mathrm{M}_{\mathrm{w}} 5.5$ Acıpayam earthquake was performed by using and evaluating existing geological and geotechnical data, site investigation in study area after the earthquake and seismicity of the region.

\section{Tectonics and seismic activity of the Burdur- Fethiye fault zone}

The Burdur-Fethiye fault zone is an active fault zone, produced earthquakes with a magnitude of 7.1 in Burdur Province on 03.10.1914 and in Fethiye District in Muğla Province on 25.04.1957 (Table 1).

${ }^{*}$ Corresponding author/Yazışılan Yazar 

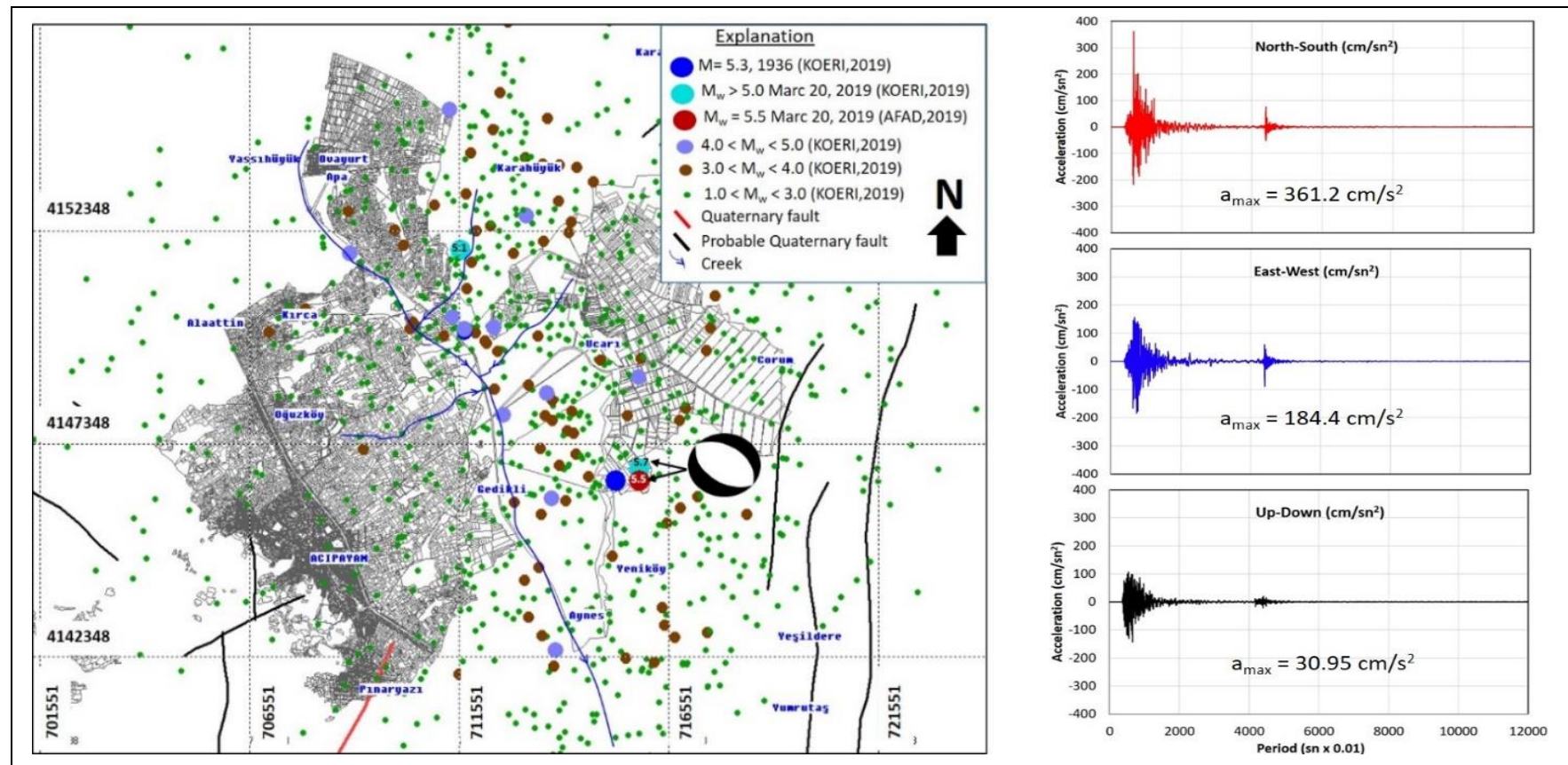

Figure 1(a): Epicenters of 20 March 2019 earthquakes on the tectonic map and urban planning map of Acıpayam on SLOPAC program [15]. (b): Acceleration records of Acıpayam strong motion station [3].

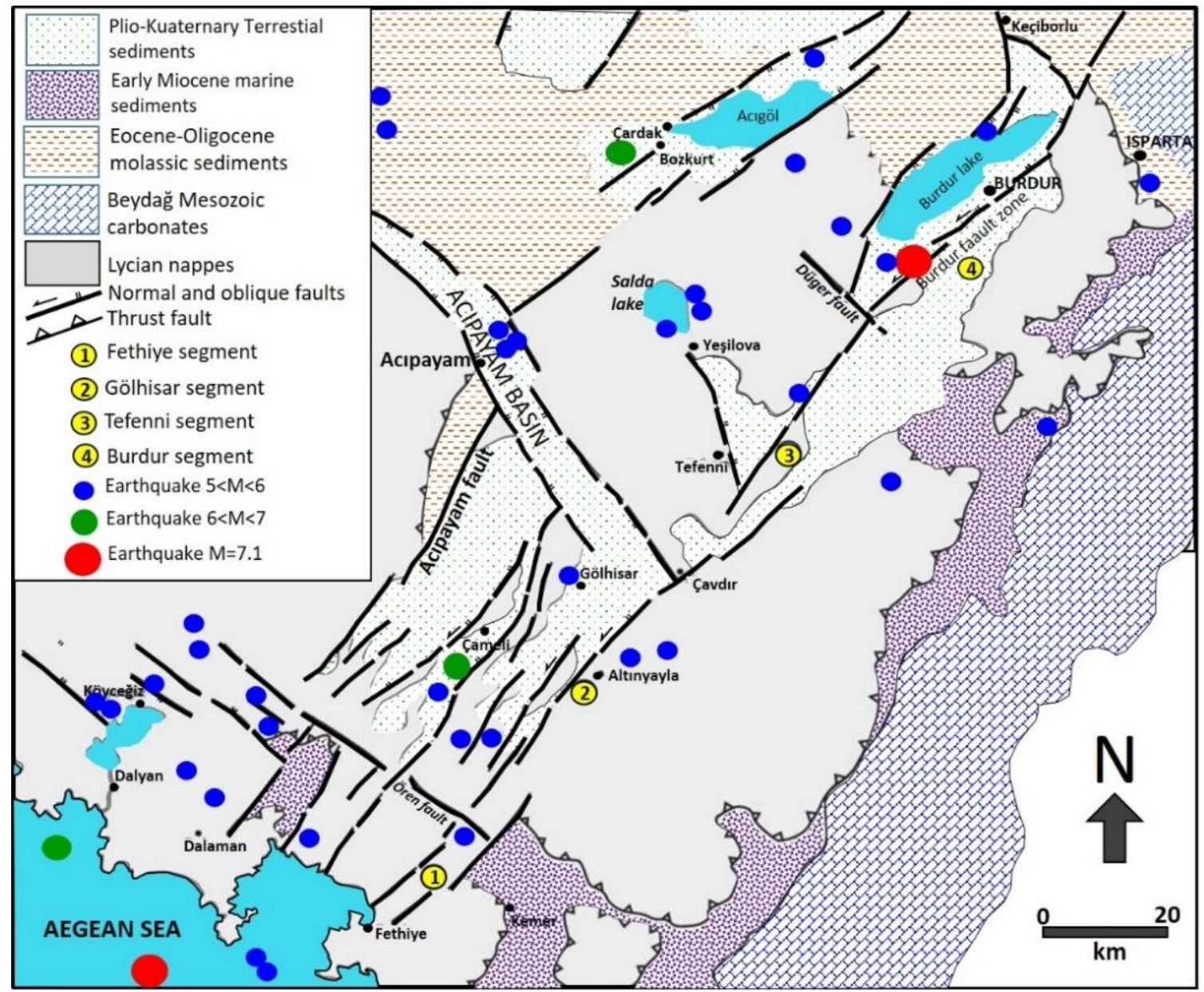

Figure 2. Relationship of between tectonic zones located in the Burdur-Fethiye Fault Zone [12] and earthquake epicenters of M>5 [1] since 1900. 
Table 1. Earthquakes occurred in Burdur-Fethiye Fault Zone between 1900 and April 2019 1[1], 2[2].

\begin{tabular}{ccc}
\hline Date & Place & Magnitude \\
\hline 03.10 .1914 & Burdur & $1 \mathrm{M}_{\mathrm{s}}=7.0$ \\
03.01 .1926 & Gölhisar - Burdur & $1 \mathrm{M}_{\mathrm{s}}=6.1$ \\
08.12 .1936 & Uçarı Acıpayam - Denizli & ${ }^{2} \mathrm{M}_{\mathrm{s}}=5.3$ \\
25.04 .1957 & Fethiye - Muğla & ${ }^{1} \mathrm{M}_{\mathrm{s}}=7.1$ \\
14.01 .1969 & Fethiye - Muğla & ${ }^{1} \mathrm{M}_{\mathrm{s}}=6.2$ \\
12.01 .1971 & Burdur & ${ }^{1} \mathrm{M}_{\mathrm{s}}=6.2$ \\
06.10 .2012 & Fethiye - Muğla & ${ }^{1} \mathrm{M}_{\mathrm{s}}=6.0$ \\
29.10 .2007 & Çameli-Denizli & ${ }^{1} \mathrm{M}_{\mathrm{s}}=5.1$ \\
20.03.2019 & Yeniköy Acıpayam-Denizli & ${ }^{1} \mathrm{M}_{\mathrm{w}}=5.5$ \\
31.03 .2019 & Karahüyük Acıpayam- & ${ }^{2} \mathrm{M}_{\mathrm{s}}=5.1$ \\
& Denizli \\
\hline
\end{tabular}

The magnitude of the post-1900 earthquakes that occurred in the inner and central parts of this fault zone did not exceed 6.2 (Figure 2). On the plain of Acıpayam, a 5.3 magnitude earthquake occurred in 1936 centered on Uçarı neighborhood. The epicenter of this earthquake is very close to the 20 March 2019 earthquake, with a recurrence of the earthquake in 83 years [13], [14].

Seismic activity of Acıpayam fault in Holocene was dated between $3030 \pm 30 \mathrm{BP}$ and $2410 \pm 30 \mathrm{BP}$ by [17] based on the trench microstratigraphy, structural pattern and ${ }^{14} \mathrm{C}$ dating on the samples take in a fault trench survey in Ören section of the Acıpayam fault.

\section{Geology and tectonics of Acıpayam basin}

Acıpayam Basin is a N-S extending Neogene basin in BurdurFethiye Fault Zone. Topographic altitude of the basin varies from $850 \mathrm{~m}$ to $950 \mathrm{~m}$ and, the surface water of the basin drains out into Dalaman creek at SW. Mesozoic and Cenozoic rocks form high mountains bounding the basin.

Mesozoic (Trias-Jura-Cretaceous) rocks are composed of carbonated and ophiolitic rock groups belong to Lycian nappes. The Mevlütler region, southwest of the Acıpayam district center, is one of the places where ophiolitic rocks are well observed [18]. The Cenozoic units consist of early Miocene conglomerates, shallow marine limestone [19] and late Miocene-Pliocene period alluvial, fluvial and lake sediments [20], [21], [22]. The morphology of the N-S trending fault along the western edge of Mount Mall, which borders the basin from the east, is quite evident (Figure 3). In the middle of the basin, a normal fault line having a N-S strike and dipping to the west has developed. Bedirbey, Yeniköy and Uçarı (Figure 3) villages are settled on this fault zone. The epicenter of the 5.5 magnitude earthquake, which occurred at 9.34 am on March 20, 2019 , falls on this fault line [14].

The younger units of the Quaternary period consist of lacustrine, fluvial, alluvial and colluvial deposits along the western slopes of the Malı month $(1745 \mathrm{~m})$ in YumrutaşYeşildere-Corum neighborhoods in the east.

After 20 March 2019 earthquake, surface cracks were observed in the south of Yeniköy district, with a direction of $\mathrm{N}^{\circ} \mathrm{E}$ and a length of approximately $1500 \mathrm{~m}$ and a width of $1-4 \mathrm{~cm}$ (Figure 3). The surface crack developed on a possible fault surface in the contact zone between the Pliocene lacustrine limestone and alluvium [14].

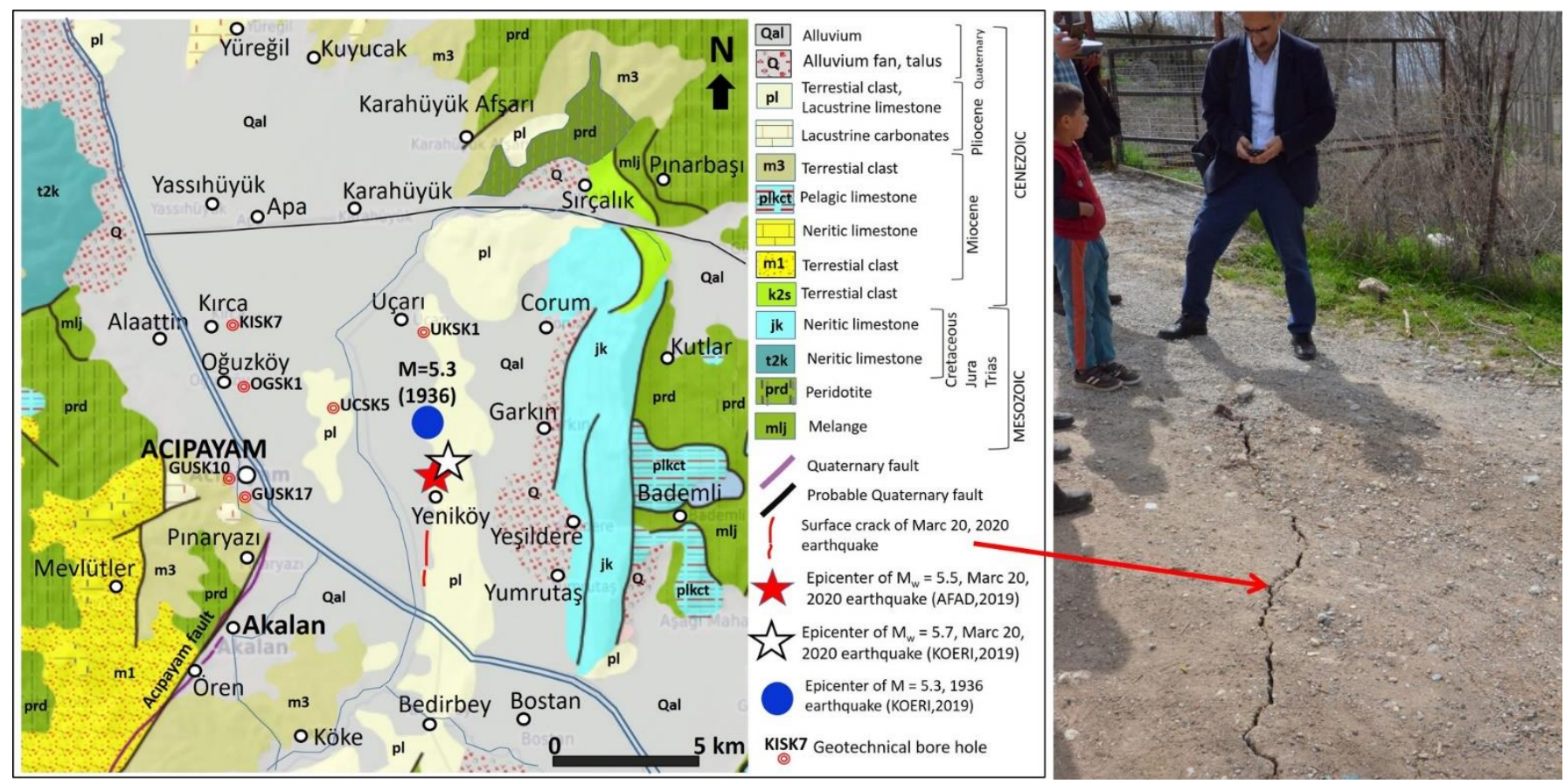

Figure 3. Geology and tectonic outlines of Acıpayam and surroundings [23],[24],[25],[14], earthquakes M>5 since 1900 [1],[2] and geotechnical borehole locations. 


\section{Geotechnical properties of soils in the Acıpayam basin}

The Acıpayam Plain has a mostly alluvial ground structure and is generally composed of silty, sandy and clayey units. As a result of the decomposition of the lacustrine limestone of Pliocene age in the inner and eastern parts of the plain, clayey, silty and sandy alluvial units are yellowish-beige in some places due to the high carbonate content in the lowland floor of the basin. As part of the work carried out by [26]-[28], and geotechnical boreholes were drilled in the area between Acıpayam district center, Oğuzköy, Kırca, Uçarı, Yeniköy and Pınaryazı (Figure 3).

Borehole locations were drawn on urban planning and geological maps on a geological and geotechnical information system software written by [15] and applied to Denizli city [16] (Figure 1).

KISK7 geotechnical borehole was drilled in the Kirca village having $15 \mathrm{~m}$ depth [29]. Groundwater level in the borehole is 1.8 $m$ deep from ground surface. Soil profile of the borehole made up of soft sediments in the first $12.5 \mathrm{~m}$ from the ground surface. Standart penetration test (SPT) values at this depth change from 10 to 14. Grain size distribution curves of soil samples are given in Figure 7. Soil sample of $4 \mathrm{~m}$ depth consists of $13.33 \%$ gravel, $70.28 \%$ sand and $13.33 \%$ silt and clay. Soil type of the sample according to Unified Soil Classification System [37] is SW (well graded sands and gravely sands). This soil is liquefiable soil but in the field liquefaction was not observed in this location after $M=5.5$ earthquake on 19 March 2019. Soil sample of $12 \mathrm{~m}$ depth contains $0.75 \%$ gravel, $28.9 \%$ sand and $70.35 \%$ silt and clay. Soil type of the sample in Unified Soil Classification System [37] is CL (inorganic clays of low to medium plasticity, gravely, sandy and silty clays).

According to the bounds for liquefiable soils [35] and 70.35\% of silt and clay content, this soil is not liquefiable (Figure 4).

OGSK1 geotechnical borehole was drilled in Oğuz village and it has $15.5 \mathrm{~m}$ depth [28]. Groundwater level in the borehole is $1.1 \mathrm{~m}$ deep from ground surface. Soil profile of the borehole from ground surface to the bottom contains $0.4 \mathrm{~m}$ of vegetable soil, $1.6 \mathrm{~m}$ tick sand, $4.5 \mathrm{~m}$ gravely clayey sand, $4.5 \mathrm{~m}$ clayey sand and $3 \mathrm{~m}$ gravely clayey sand (Figure 4 ).

SPT values from $1.5 \mathrm{~m}$ to $6 \mathrm{~m}$ varies from 11 to 24 . The soil profile after $6 \mathrm{~m}$ gets stiffer with increasing SPT values from 36 to over 50. Grain size distribution curves of soil samples are given in Figure 4 . Soil sample of $4.5 \mathrm{~m}$ depth consists of $21.58 \%$ gravel, $33.06 \%$ sand and $43.36 \%$ silt and clay. Soil type of the sample in Unified Soil Classification System [37] is SC (clayey sands, sand clay mixture). This soil is not liquefiable [35] (Figure 7).

UCSK5 geotechnical borehole was drilled in Uçarı village and it has a depth of $16 \mathrm{~m}$. The Groundwater level in the borehole is $1.5 \mathrm{~m}$ below the ground surface [26].
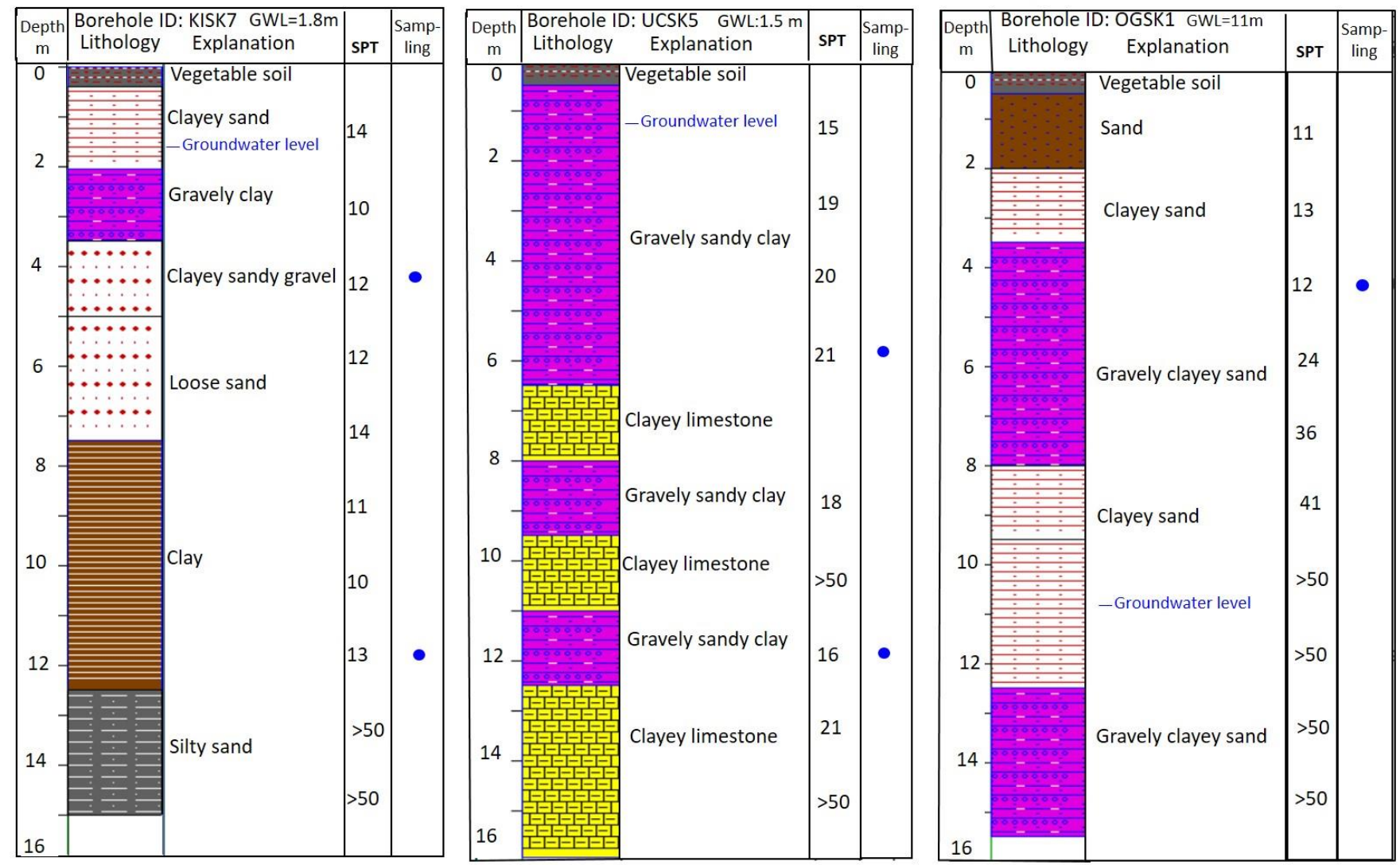

Figure 4. Geotechnical logs of the boreholes numbered as KISK7, OGSK1 and UCK5 in the Acıpayam Basin. 
Soil profile of the borehole from ground surface to the bottom contains $0.4 \mathrm{~m}$ vegetable soil and succession of gravely sandy clay and clayey limestone. Gravely sandy clay layers have STP vales between 15 and 21 while clayey limestone levels have SPT values bigger than 50 (Figure 4). Soil samples of $6 \mathrm{~m}$ and $12 \mathrm{~m}$ depths contain $82.44 \%$ and $76.04 \%$ silt and clay respectively. Soil type of the both samples in Unified Soil Classification System [37] are CL. Soils in both levels are not liquefiable [35] (Figure 7).

GUSK10 geotechnical borehole was drilled in the center of the Acıpayam District having $11 \mathrm{~m}$ depth [29]. Groundwater level is deeper than the depth of the borehole. Soil profile from ground surface to the bottom of the borehole contains $0.4 \mathrm{~m}$ vegetable soil and $10.6 \mathrm{~m}$ weathered claystone (Figure 5). Soil sample taken at $3 \mathrm{~m}$ depth consists of $28.42 \%$ sand and $71.58 \%$ clay. Soil type of the sample in Unified Soil Classification System [37] is CL. Soil liquefaction is not possible in this borehole location [35] (Figure 7).

GUSK17 borehole was drilled in the center of the Acıpayam District having $11 \mathrm{~m}$ depth. Groundwater level is deeper than the depth of the borehole. Soil profile of GUSK17 borehole, having $11 \mathrm{~m}$ depth and located in the district center, from ground surface to the bottom contains $0.4 \mathrm{~m}$ organic soil and $10.6 \mathrm{~m}$ sandy stiff clay. The SPT values in the borehole were bigger than 50 (Figure 5).

Most of the buildings around GUSK10 and GUSK17 borehole locations had no damage. There are slightly damaged buildings having chimney toppling and fissures in hollow brick built walls. Stiffness of weathered claystone and sandy stiff clay having SPT values bigger than 50, and having groundwater levels deeper than borehole depths $(>12 \mathrm{~m})$ had an important effect on the slight damages of the structures at these borehole locations.

UKSK1 borehole was drilled in Uçarı village and $10 \mathrm{~m}$ in the lacustrine limestone was cut through the borehole. The groundwater level is $5 \mathrm{~m}$ deeper than the ground surface [30]. Lacustrine limestone is weathered and, has pores and karstic cavity (Figure 5). Groundwater discharging through karstic limestone in western area of Uçarı village forms the lake of Uçarı (Figure 6). Weathering, karstic cavity, groundwater pressure in lacustrine limestone and close distance to the earthquake epicenter location had an important influence on the heavy damages of the masonary structures in Uçarı village.

[31] compiled some data on the earthquakes in Turkey and developed relations between the magnitude of the earthquake and the distances of the areas where liquefaction occurred and did not occur. The average distance from the epicenter of the earthquake where liquefaction may occur can be calculated with the following equation:

$$
\mathrm{R}=36 \mathrm{M}_{\mathrm{s}}-200 \text { (average) [31] }
$$

If the distance $\mathrm{R}$ is less than zero, liquefaction does not occur. For values greater than zero, local ground condition and groundwater level values are effective. For the Acıpayam earthquake, $R=-2 \mathrm{~km}$ has been obtained. It is very close to $M_{s}$ $=5.56$ liquefaction magnitude of lower boundary [31] but outside the lower limit of the possibility of liquefaction.

Liquefaction analyses of the soils sampled in OGSK1, UCSK5, KRSK7 and GUSK10 boreholes were performed by using the suggested method of [36] for the $M_{w} 5.5$ earthquake. The factor of safety against liquefaction for all samples were obtained bigger than 1.5. This means that, these soils are not liquefiable under the effect of $\mathrm{M}_{\mathrm{w}} 5.5$ Acıpayam earthquake.
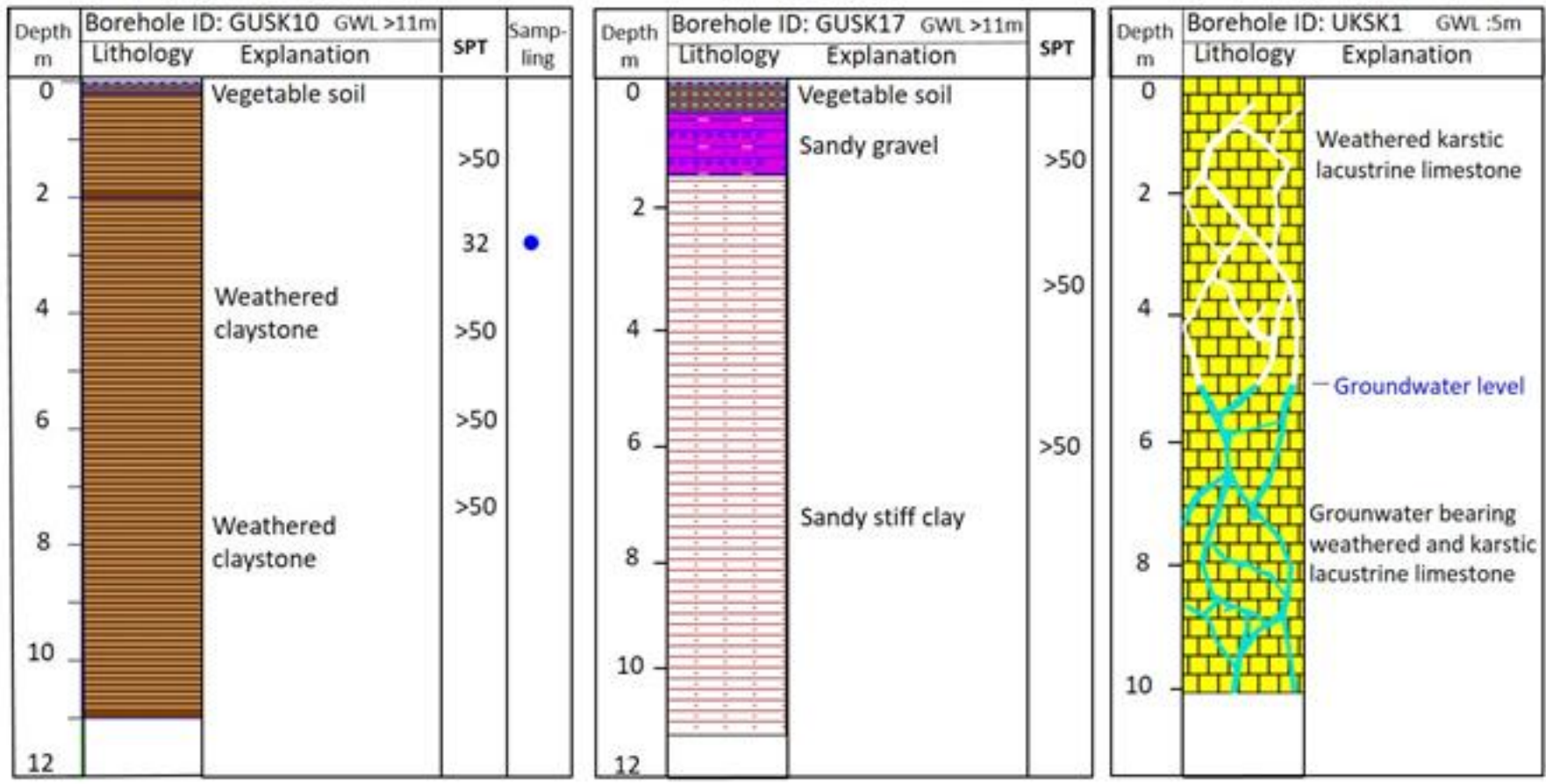

Figure 5. Geotechnical logs of the boreholes numbered as GUSK10, GUSK17, UKSK1 in the Acıpayam Basin. 

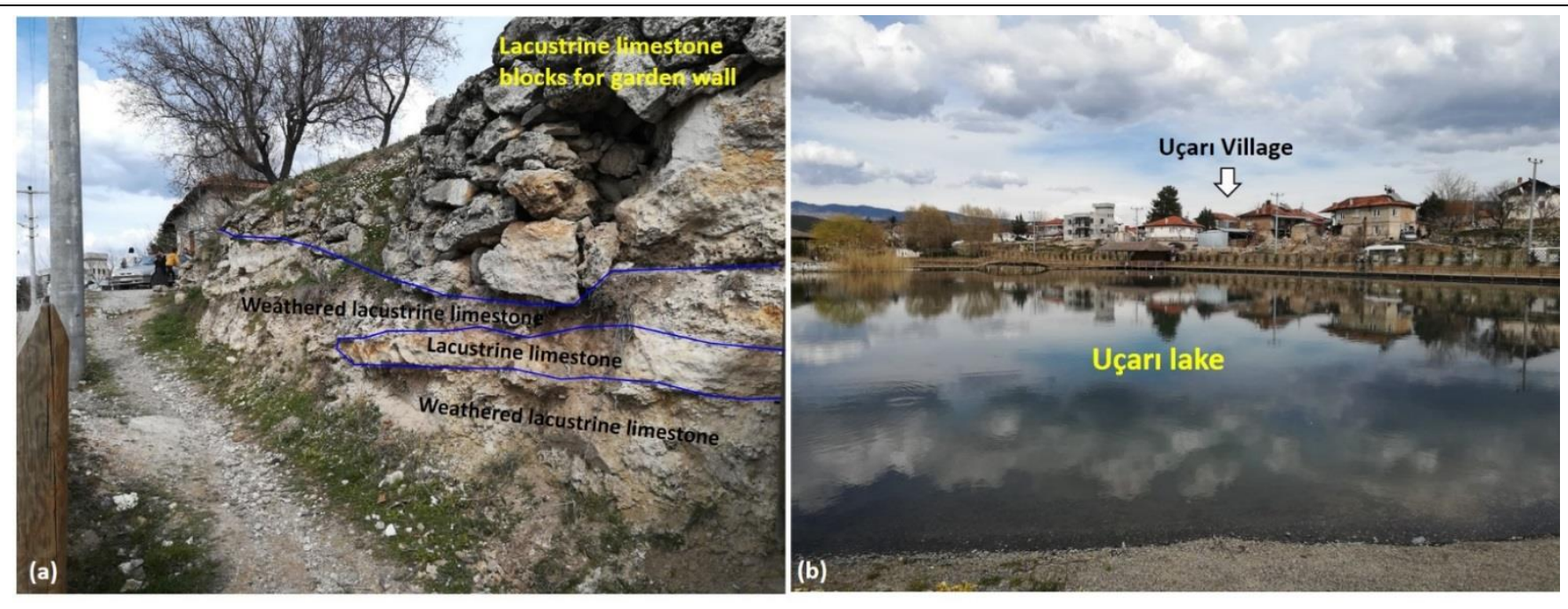

Figure 6(a): Field view of weathered lacustrine limestone in Uçarı village settlement area, (b): Uçarı village and the lake of Uçarı.

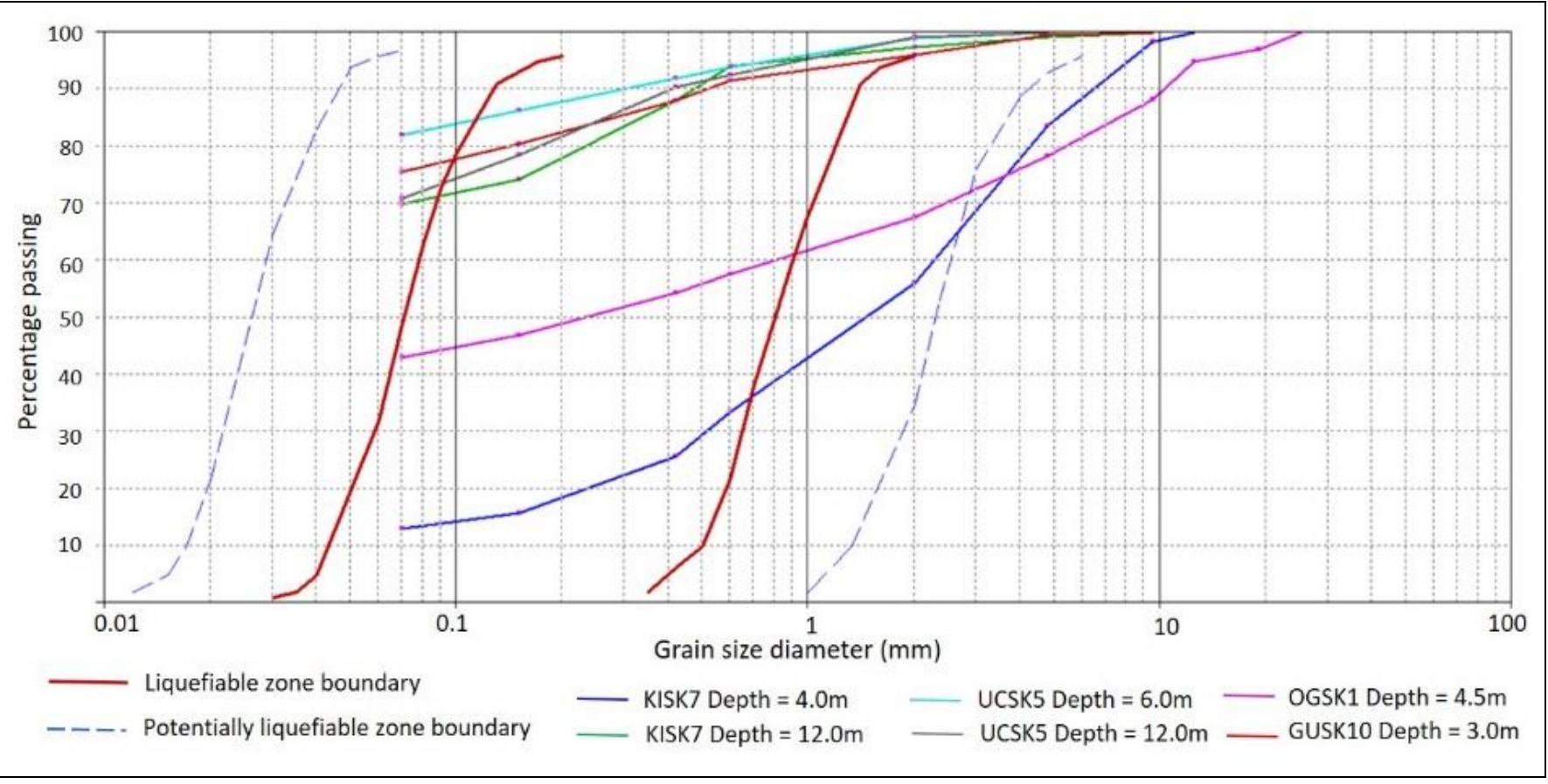

Figure 7. Grain size distribution of soils sampled in different boreholes in the Acıpayam basin with known bounds for liquefiable soils [35].

Liquefaction phenomenon was not observed in these drilling sites as a result of the earthquake that occurred on 20 March 2019. Due to the fact that $R$ is less than zero, and high ratio of clay, silty and fine grain in the soil structure of the Acıpayam basin liquefaction did not occurred.

Shear wave velocities of top soils obtained from multi-channel analysis of surface wave (MASW) measurements at each borehole location by using WZG-12A brand seismic measurement device having 12 channels [26]-[30] were analysed and interpreted (Table 2).

Shear-wave velocities $\left(\mathrm{V}_{\mathrm{s}}\right)$ at KISK7, UCSK5 and OGSK1 boreholes are 190 m/s, 189 m/s and 233 m/s, respectively. The groundwater depth from ground surface in KISK7 and UCSK5 boreholes are $1.8 \mathrm{~m}$ and $1.5 \mathrm{~m}$ in turn while it is $11 \mathrm{~m}$ deep in OGSK1 borehole. Soil profile at these locations contains soft soils between ground surface and $6 \mathrm{~m}$ depth. Shear-wave velocities of soils at GUSK10 and GUSK17 borehole locations in the Acipayam district center are $343 \mathrm{~m} / \mathrm{s}$ and $443 \mathrm{~m} / \mathrm{s}$, respectively. At these locations there is hard soil profile and groundwater was not observed in the boreholes. Shear-wave velocity at UKSK1 location in Uçarı village is $430 \mathrm{~m} / \mathrm{s}$ and litology in the borehole is lacustrine limestone having cavity, weathering due to groundwater $5 \mathrm{~m}$ below ground surface. 
Table 2. Shear-wave velocities of soils, amplification factors and local soil types at borehole locations.

\begin{tabular}{lccccc}
\hline $\begin{array}{c}\text { Measurement } \\
\text { Location }\end{array}$ & $\begin{array}{c}\text { Shear-wave velocity } \\
\mathrm{V}_{\mathrm{s}}(\mathrm{m} / \mathrm{s})\end{array}$ & $\begin{array}{c}\text { A (Joyner \& Fumal, } \\
1984)\end{array}$ & $\begin{array}{c}\text { A (Midorikawa, } \\
1987)\end{array}$ & $\begin{array}{c}\text { A (Borcherdt et al, } \\
\text { 1991) }\end{array}$ & $\begin{array}{c}\text { Local soil } \\
\text { type [39] }\end{array}$ \\
\hline KISK7 & 190 & 2.17 & 2.92 & 3.68 & ZD \\
UCSK5 & 189 & 2.17 & 2.93 & 3.70 & ZD \\
OGSK1 & 233 & 1.98 & 2.58 & 2.00 & ZD \\
GUSK10 & 343 & 1.66 & 1.04 & 2.04 & ZC \\
GUSK17 & 443 & 1.48 & 1.58 & ZC \\
UKSK1 & 430 & 1.50 & 1.79 & 1.63 & ZC \\
\hline
\end{tabular}

ZD: Medium dense - dense sand, gravel or stiff clay strata [39], ZC: Layers of very dense sand, gravel and stiff clay, or weathered and too fractured weak rocks [39].

Soil amplification factors (A) of soils for peak ground velocities at the borehole locations were calculated by using equations 1 2 and 3 given by [32], [33] and [34], respectively. Hazard level depending on soil amplification criterion of a settlement area is studied in three groups for microzonation investigations as in Table 3 [38].

$$
\begin{aligned}
& A=68 V_{s}{ }^{-0.6} \\
& A=23 V_{s}{ }^{-0.45} \\
& A=700 / V_{s}
\end{aligned}
$$

Table 3. Hazard levels depending on soil amplification criterion in microzonation studies [38].

\begin{tabular}{cc}
\hline $\begin{array}{c}\text { Soil amplification } \\
\text { factor }\end{array}$ & Hazard level \\
\hline $0.0-2.0$ & Low \\
$2.0-4.0$ & Medium \\
$4.0-6.0$ & High \\
\hline
\end{tabular}

[33] equation gives lower A values than [32] and [34] equations (Table 2). Maximum A values of at KISK7, UCSK5 and OGSK1 locations are $3.68,3.70$ and 3.0 respectively and, they are in medium hazard level as given in Table 2 [38]. At these locations adobe, brick made masonary houses were heavily damaged due to earthquake. Reinforced structures were slightly damage and non-damaged (Figure 8a,b; Figure 9a,b; Figure 10a,b).

5.5 magnitude Acıpayam earthquake caused slight damages on precast factory structures built on soft soils in the Acıpayam basin. These damages are usually fissures and cracks at the connection parts of precast elements. Such as, beam and wall connections, beam and column connections, column and wall connections. There are also damages on suspended ceilings of the factory structures in the basin (Figure 11a). Single-storey reinforced structures, built on soft soil sediments in the basin, are usually undamaged (Figure 11b). However, multi-storey reinforced modern structures have damages on the hollow brick built walls in the basement floor (Figure 11b) masonary roof floor (Figure 8a). These reinforced structures had no damages on their beams and columns.
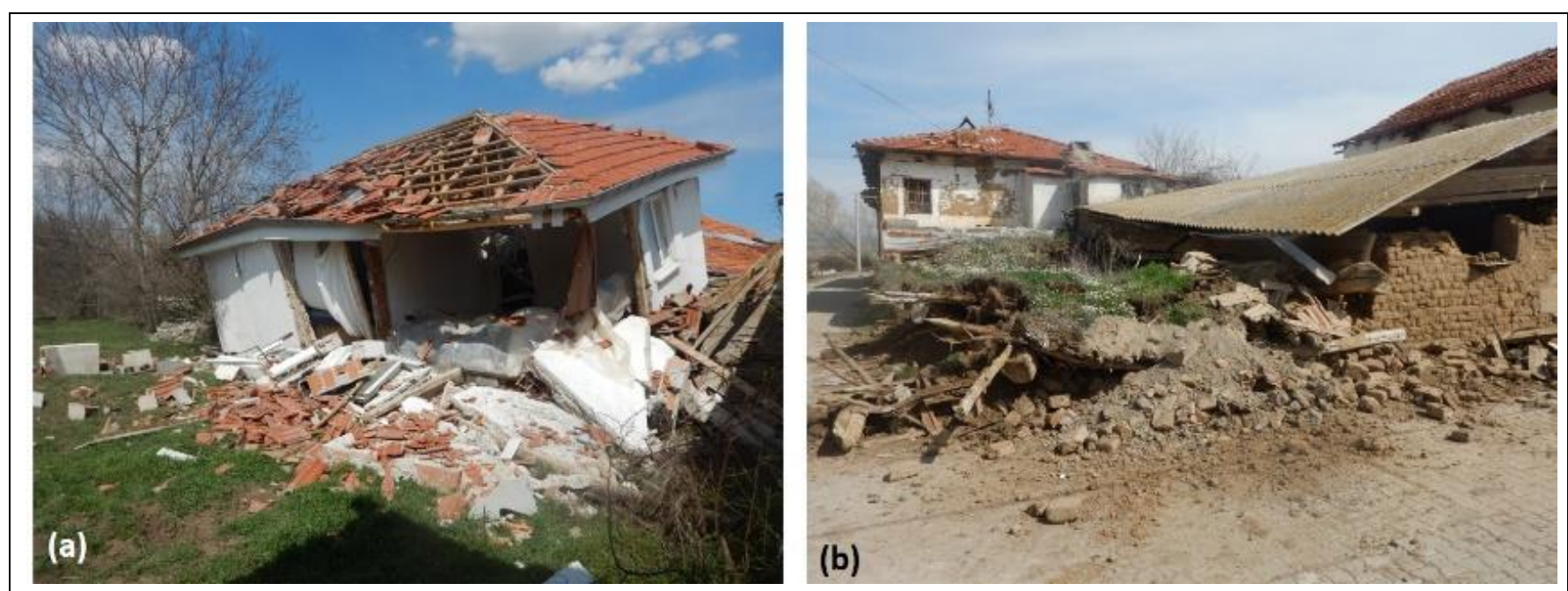

Figure 8(a): Heavily damaged hollow brick structure, (b): Collapsed adobe structure in Kirka village. 


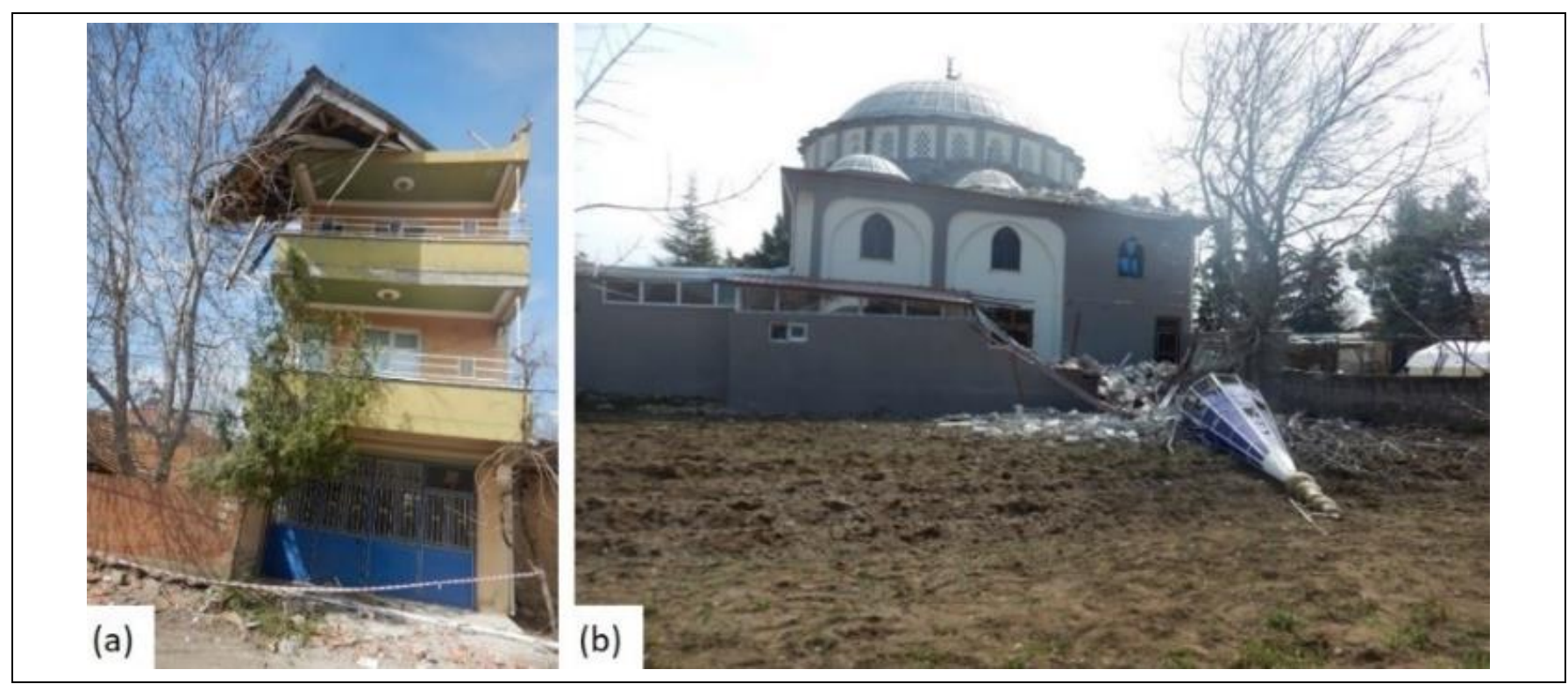

Figure 9(a): Hollow brick built roof floor failure of a reinforced structure. (b): heavily damaged masonary mosque in Oğuz village.
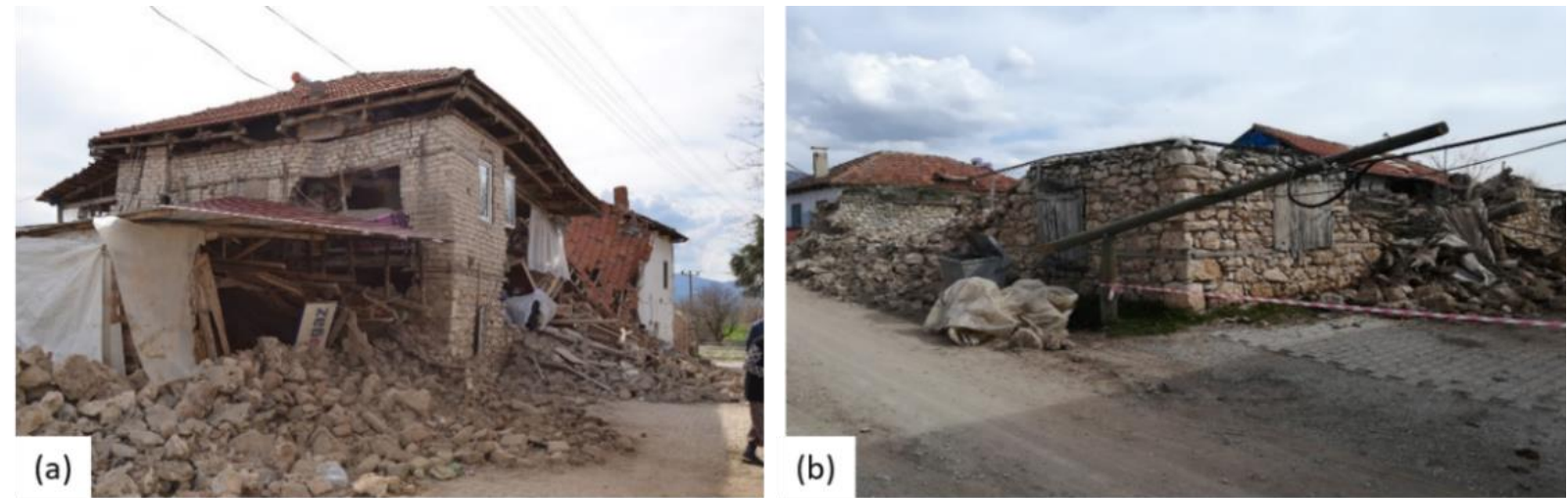

Figure 10(a): Collapsed adobe structure, (b): heavily damaged masonary structure and broken electric pole in Uçarı village.

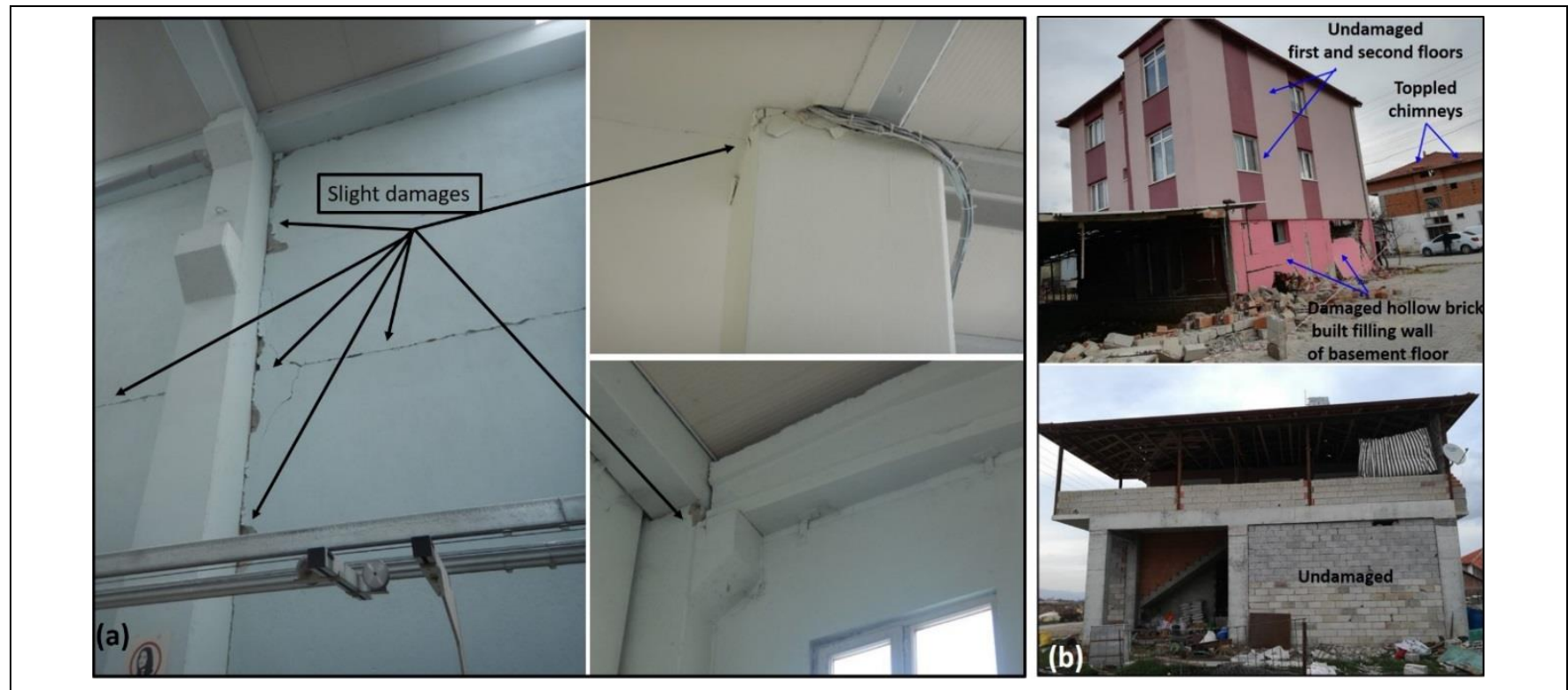

Figure 11(a): Damages on precast concrete modern textile factory structure in Yassıhüyük village, (b): Partly damaged three-storey reinforced structure and undamaged single-storey reinforced structure in Apa village. 
Soil amplification factor of soils at UKSK1 location in Uçar village is 1.79 . At this location and in close area adobe, brick made masonary houses were heavily damaged and weak reinforced structures were moderately damaged. As the epicenter of the earthquake is $4 \mathrm{~km}$ close to Uçarı village, heavy damage on the masonary structures occurred during the earthquake.

\section{Conclusions}

In the Acıpayam extensional area of the Burdur-Fethiye fault zone, magnitude 5 and above 1 earthquake occurred between years 1900 and 2019. The epicenter of this 5.3 magnitude earthquake, which occurred on 08.12.1936, is in the Uçarı district and is approximately $3 \mathrm{~km}$ north of the 5.5 magnitude Yeniköy earthquake, which occurred on March 20, 2019. This shows that the same earthquake was repeated 83 years later. Surface cracks ranging from $\mathrm{N} 5^{\circ} \mathrm{E}$ to $\mathrm{N} 20^{\circ} \mathrm{W}$ with a length of about $1.5 \mathrm{~km}$ and width up to $4 \mathrm{~cm}$ were observed in the southern part of Yeniköy village.

The epicenter of the $M=5.5$ earthquake is $1 \mathrm{~km}$ north of Yeniköy and $4 \mathrm{~km}$ south of Uçarı village. The structural damage in Yeniköy village settlement area, which is located on the lacustrine limestone unit, is less than the damage in Uçarı village. The main reason for this can be interpreted as the fact that the lacustrine limestone in Uçarı village contain groundwater and that the degradation of limestone is greater than in Yeniköy area. Structural damages in both neighborhoods are mostly in masonry adobe structures, stone masonry structures with clay binders, and masonry structures built with hollow brick. Only chimney topples occurred in reinforced concrete structures.

The damage is greater in Karahüyük, Apa, Kırca and Oguzköy neighborhoods located on the soft alluvial sediments where groundwater level is close to the ground surface. In addition to masonry structures in these neighborhoods, slight damage to reinforced concrete structures also occurred. The main reason for this is higher values of ground amplification factors of soft alluvial soils.

Soil liquefaction was not observed although groundwater level is close to the ground surface. The high fine (silt and clay) contents (changing between $40 \%$ and $80 \%$ ) of the alluvial sediments were effective in preventing the phenomenon of liquefaction as a result of the 5.5 magnitude earthquake.

As the Acıpayam basin is an extensional basin in the BurdurFethiye Fault Zone, NE-SW trending fault called Acıpayam Fault extending through Pınaryazı, Akalan can result in bigger earthquake magnitude than normal faults in the basin. Therefore, the region should be prepared to be resistant for $M>6.5$ earthquakes.

\section{Acknowledgment}

The authors thank to Osman Kurt, Duygu Kondakçı Soyyiğit and Bünyamin Ağar from Denizli Metropolitan Municipality, Tuğba Sarayköylü from DSİ, Yiğithan Say, Didem Özyurt, Umut Can Karagöz, Mehmet Reşber from Pamukkale University and Acipayam Municipality for their various logistic support to this study.

\section{References}

[1] AFAD. "Afet ve Acil Durum Yönetimi Başkanlığı". www.deprem.afad.gov.tr (24.03. 2019).

[2] KOERI. "Kandilli Observatory and Research Institude". www.koeri.boun.edu.tr, (28.03.2019).

[3] AFAD. 20 Mart 2019 Acaipayam (Denizli) Mw 5.5 Depremine ilişkin ön değerlendirme Raporu (in Turkish), www.deprem.afad.gov.tr (28.03. 2019).

[4] Hançer M, Kenanoğlu N. "Geological Interpretation of March 20, 2019 Acıpayam (Denizli Turkey) Earthquake". $136^{\text {th }}$ Proceedings of Academic World International Conference, Rome, Italy, 20-21 July 2019.

[5] McKenzie DP. Active tectonics of the Alpine-Himalayan Belt: The Aegean sea and its surronding regions, Geophysical Journal of the Royal Astronomical Society, 55, 217-254, 1978

[6] Koçyiğit A. "Hoyran gölü (Isparta büklümü) dolayının tektoniği". TJK Bülteni, 26(1), 1-10, 1983.

[7] Karaman ME. Isparta Güneyinin Temel Jeolojik Özellikleri. TJK Bülteni, 33, 57-67, 1990.

[8] Taymaz T, Price SP. "The 12.05.1971 Burdur earthquake sequence: A synthesis seismological and geological observations". Geophysical Journal International, 108, 589-603, 1992.

[9] Barka A, Reilinger R, Şaroğlu F, Sengör AMC. “The Isparta Angle: Its evolution and importance in the tectonics of the eastern Mediterranean region". International Earth Science Colloquium on Aegean Region, İzmir, Türkiye, 9-14 October, 1995.

[10] Yağmurlu F. "Burdur fayının sismotektonik özellikleri". Batı Anadolu'nun Depremselliği Sempozyumu-BAD SEM 2000 Bildiriler Kitabı, İzmir, Türkiye, 2000.

[11] Șentürk M. Acıgöl ve Burdur Gölleri Arasındaki Bölgenin Sismotektonik Özellikleri, Yüksek Lisans Tezi, Süleyman Demirel Üniversitesi, Isparta, Türkiye, 2003.

[12] Bozcu M, Yağmurlu F, Şentürk M. "Fethiye-Burdur Fay Zonunun Bazı Neotektonik ve Paleosismolojik Özellikleri (in Turkish), GB-Türkiye". Jeoloji Mühendisliği Dergisi, 31(1), 25-48, 2007.

[13] Kumsar H, Özkul M, Semiz B. “20 Mart 2019 AcıpayamYeniköy (Denizli) M=5.5 Depremlerinin Ön Değerlendirme Raporu”. Denizli, Türkiye, 21, 2019.

[14] Kumsar H, Özkul M, Semiz B. "Geological and Geotechnical Investigation of 20 March $2019 \mathrm{M}_{\mathrm{w}} 5.5$ Acıpayam (Denizli) Earthquake". National Symposium on Engineering Geology and Geotechnics-ENGGEO'2019, Denizli, Turkey, 03-05 October 2019.

[15] Kumsar, H. Mine Slope Stability Assessment by Using InerSlice Force Transmission Theory. PhD Thesis, Deparment of Mineral Resources Engineering, Nottingham University, UK, 1993.

[16] Kumsar, H, Çelik, SB, Kaya, M. "Denizli il merkezi yerleşim alanının jeolojik, jeoteknik kent bilgi sistemi (JEO-KBS)". Pamukkale Üniv. Mühendislik Bilimleri Dergisi, 10(4), 25-31, 2004.

[17] Kürçer Z, Özdemir R, Uygun Güldoğan C, Duman TY. “The first paleoseismic trench data from Acıpayam fault, Fethiye Burdur Fault Zone, SW Turkey". Proceedings of the 14th International Congress, Thessaloniki, Greece, 25-27 May 2016, 
[18] Balcı M, Sarıkaya A, Yıldız M. "Denizli-Acıpayam Peridotit Masifinin Çatak-Mevlütler Çevresinin Jeolojisi, MTA Raporu”. Ankara, Türkiye, 6447, 1976. (yayımlanmamış).

[19] Büyükmeriç Y. "Kale-Tavas ve Acıpayam Havzalarında erken miyosen çökellerinin mollusk biyostratigrafisi (Denizli, GB Türkiye) (in Turkish)”. MTA Dergisi, 155, 49-73, 2017.

[20] Erten H. "Acıpayam-Çameli Karasal Neojen İstifinin Stratigrafisi ve Mikromemeliler Yönünden İncelenmesi". Yüksek Lisans Tezi, Pamukkale Üniversitesi, Denizli, Türkiye, 2002.

[21] Alçiçek MC, Kazancı N, Özkul M, Șen Ş. “Çameli (Denizli) Neojen Havzası'nın tortul dolgusu ve jeolojik evrimi (in Turkish)". MTA Dergisi, 128, 99-123 2004.

[22] Alçiçek MC, Kazancı N, Özkul M. "Multiple rifting pulses and sedimentation pattern in the Çameli Basin, southwestern Anatolia, Turkey". Sedimentary Geology, 173, 409-43, 2005.

[23] Emre Ö, Duma, TY, Özalp S, Elmacı H, Olgun Ş, Şaroğlu "F1/1.250.000 Ölçekli Türkiye Diri Fay Haritası". Maden Tetkik ve Arama Genel Müdürlüğü Özel Yayınlar Serisi, Ankara, Türkiye, 2013.

[24] MTA. "Maden Tetkik ve Arama Genel Müdürlüğü". http://yerbilimleri.mta.gov.tr/anasayfa.aspx ${ }_{\perp}$ (30.04.2019).

[25] Akbaş B, Akdeniz N, Aksay A, Altun İ, Balcı V, Bilginer E, Bilgiç T, Duru M, Ercan T, Gedik İ, Günay Y, Güven İH, Hakyemez HY, Konak N, Papak İ, Pehlivan Ş, Sevin M, Şenel M, Tarhan N, Turhan N, Türkecan A, Ulu Ü, Uğuz MF, Yurtsever A, ve diğerleri. "Türkiye Jeoloji Haritası". Maden Tetkik ve Arama Genel Müdürlüğü Yayını, Ankara, Türkiye, 2002.

[26] Şekerci H, Kocabaş A. "Denizli İli Acıpayam İlçesi Uçarı Yolu Üzeri N22B08A2C, N22B08B1D Paftalarında Yeralan Çalışma Alanının İmar Planına Esas Jeolojik-Jeoteknik Etüt Raporu (in Turkish). Denizli, Türkiye, 165, 2016.

[27] Şekerci H, Kocabaș A. "Denizli İli Acıpayam İlçesi Kırca Mahallesi N22B02B3C, N22B02B3D, N22B02B4C, N22B02B4D, N22B02C1A, N22B02C1B, N22B02C1C, N22B02C1D, N22B02C22A, N22B02C2B, N22B02C4B, N22B03A4D Paftalarında Yeralan Çalıșma Alanının İmar Planına Esas Jeolojik-Jeoteknik Etüt Raporu (in Turkish)”. Denizli, Türkiye, 247, 2018.

[28] Şekerci H, Kocabaș A. "Denizli İli Acıpayam İlçesi Oğuz Mahallesi N22B02C3A, N22B02C3B, N22B02C3C, N22B02C3D, N22B02C4AD Paftalarında Yeralan Çalışma Alanının İmar Planına Esas Jeolojik-Jeoteknik Etüt Raporu (in Turkish)”. Denizli, Türkiye, 205, 2018.
[29] Kocabaş A, Şekerci H. "Denizli İli Acıpayam İlçesi Güneybatısında Yeralan Çalışma Alanının İmar Planına Esas Jeolojik-Jeoteknik Etüt Raporu (in Turkish)”. Denizli, Türkiye, 201, 2015.

[30] Kocabaş A. Şekerci H. "Denizli İli Acıpayam İlçesi, Ucarı Mahallesi, N22B04A3C, N22B04B4A, N22B04B4C, N22B04B4D, N22B04D2B, N22B04C1A, N22B04C1B, N22B04C1C Paftalarında Yeralan 1.005.746 $\mathrm{m}^{2}$ lik Alanının Mevzii İmar Planına Esas Jeolojik-Jeoteknik Etüt Raporu (in Turkish)”. Denizli, Türkiye, 239, 2017.

[31] Aydan Ö, Kumsar H. "Yeni bir sıvılașma tahmin yöntemi ve uygulamaları". II. İzmir ve Çevresinin Jeoteknik Sorunları Sempozyumu, İzmir, Türkiye, 22-24 Ekim 1997.

[32] Midorikawa S. "Prediction of isoseismal map in the Kanto Plain deu to hypotetrtical earthquake". Journal of StructuralEngineering, 33B, 43-48, 1987.

[33] Joyner WB, Fumal TE. "Use of measured shear-wave velocity for predicting geologic site effects on strong ground motion". Proceedings of Eight World Conference on Earthquake Engineering, Sanfrancisco, USA, 21-28 July, 1984.

[34] Borcherdt RD, Wentworth CM, Janssen A, Fumal T, Gibbs J. "Methodology for predictive GIS mapping of special study zones for strong ground shaking in the San Francisco Bay region". Proceedings of the $4^{\text {th }}$ International Conference on Seismic Zonation, August, California, USA, 26-29 August 1991.

[35] Port and Harbour Research Institude of Japan. Handbook of Liquefaction Remediation of Reclaimed Land. Brookfield, UK, Balkema,1997.

[36] Youd TL, Idriss IM, Andrus RD, Dobry R, Ishihara K, Martin, GR, Arango I, Finn WDL, Koester JP, Mitchell JK, Robertson PK, Castro G, Harder Jr LF, Liao SSC, Christian JT, Hynes ME, Marcuson III WF, Moriwaki Y, Seed RB, Power MS, Stokoe II KH, "Liquefaction resistance of soils: summary report from the 1996 NCEER and 1998 NCEER/NSF Workshops on Evaluation of Liquefaction Resistance of Soils". Journal of Geotechnical and Geoenvironmental Engineering, 127(10), 817-833, 2001.

[37] ASTM. "Unified Soil Classification System (USCS) (ASTM D2487-11)". ASTM International, USA, 2011.

[38] Özçep F. Mikrobölgeleme: İlkeler ve Uygulamalar. Ankara, Türkiye, TMMOB Jeofizik Mühendisleri Odası, 2007.

[39] Türkiye Deprem Yönetmeliği. "Deprem Etkisi Altında Binaların Tasarımı İçin Esaslar". https://www.resmigazete.gov.tr/eskiler/2018/03/2018 0318M1-2-1.pdf (01.05.2020). 